\title{
GENETIC POLYMORPHISM OF RED CELL ENZYMES (AcP, EsD, GPT, 6-PGD) AND OF SERUM PROTEIN(Gc) IN FUKUSHIMA PREFECTURE
}

\author{
Sumiko ABE \\ Department of Legal Medicine, Fukushima Medical College, \\ Fukushima 960, Japan
}

\begin{abstract}
Summary The polymorphism of red cell enzymes (AcP, EsD, GPT and 6-PGD) and of serum protein (Gc) was examined in samples of unrelated individuals living in Fukushima Prefecture. Gc subtypes were determined by isoelectric focusing and immunofixation. It was found, in the formers, the gene frequencies of $\mathrm{AcP}^{\mathrm{A}}, \mathrm{EsD}^{1}, \mathrm{GPT}^{1}$ and 6-PGDA to be 0.229, 0.634, 0.623 and 0.921 , and in the latter, $\mathrm{Gc}^{1 \mathrm{~F}}, \mathrm{Gc}^{1 \mathrm{~S}}, \mathrm{Gc}^{2}$ and $\mathrm{Gc}^{\text {others }}$ to be $0.4854,0.2402,0.2469$ and 0.0276 , respectively. Two of rare phenotypic variants of $\mathrm{Gc}$ were also described.
\end{abstract}

\section{INTRODUCTION}

The numbers of genetic markers for characterization of human populations are increasing. Polymorphic systems of the red cell enzymes and of the plasma proteins are useful for demonstrating the differences and distinctions among populations. Population studies on phenotypic distribution in the red cell enzyme systems have been performed extensively in Japan (Ishimoto and Kuwata, 1973). Phenotypes of these systems are determined by a starch gel electrophoresis followed by the stainings specific for each of the enzymes. Group-specific component ( $\mathrm{Gc}$ ), the vitamin $\mathrm{D}$ binding protein, is one of human plasma proteins showing genetic polymorphism. Recently, an isoelectric focusing technique using acrylamide gel has been developed for the study of inheritance of the protein polymorphism (Viau et al., 1977). Thereby, it has become possible to divide Gc1-1 type into 3 subtypes, Gc1F-1F, 1F-1S and $1 \mathrm{~S}-1 \mathrm{~S}$, and to determine additional polymorphic variants of Gc. In the present study, we examined the polymorphic distributions and gene frequencies of the 4 red cell enzyme systems and of the Gc system in Fukushima Prefecture, and found rare variants of $\mathrm{Gc}(1 \mathrm{~A} 2-1 \mathrm{~A} 9$ and $1 \mathrm{~A} 9-1 \mathrm{~A} 9)$.

Received July 25, 1982 


\section{MATERIALS AND METHODS}

Blood samples were obtained from healthy and unrelated blood donors living in Fukushima Prefecture, northeastern part of Japan. In order to study inheritance of the Gc variants, 15 sera were collected from one family.

The genetic variations were examined in the following 4 enzymes; acid phosphatase (AcP), esterase D (EsD), glutamic-pyruvic transaminase (GPT) and 6-phosphogluconate dehydrogenase (6-PGD). The procedures of blood collection, preservation and electrophoretic analysis were in accord with those of Hopkinson et al. (1964).

Gc polymorphism was determined by the isoelectric focusing and the immunofixation (Constans et al., 1977, 1978). The former step was performed on a slab acrylamide gel of $0.5 \mathrm{~mm}$ thickness containing $5 \%$ carrier ampholyte $(\mathrm{pH} \mathrm{4-6}$, Ampholine, LKB), photopolymerized in the presence of riboflavin. After a $4 \mathrm{hr}$ migration period, the immunofixation was carried out on a cellulose acetate strip soaked with monospecific antiserum to $\mathrm{Gc}(\mathrm{DAKO})$. The immune precipitates thus obtained were stained with Coomassie Brilliant Blue.

\section{RESULT AND DISCUSSION}

Red cell enzyme systems

The gene frequencies of the 4 red cell enzyme systems were shown in Table 1. They were statistically not contradictory to the Hardy-Weinberg law in the all of 4 .

Table 1. The gene frequencies of the 4 red cell enzyme systems in Fukushima Prefecture.

\begin{tabular}{|c|c|c|c|c|}
\hline Enzyme & Phenotypes & $\begin{array}{c}\text { No. } \\
\text { observed }\end{array}$ & $\begin{array}{c}\text { No. } \\
\text { expected }\end{array}$ & $\begin{array}{c}\text { Gene } \\
\text { frequencies }\end{array}$ \\
\hline \multirow[t]{4}{*}{$\mathrm{AcP}$} & A & 58 & 54.3 & $\mathrm{AcPA} \quad 0.229$ \\
\hline & $\mathrm{BA}$ & 359 & 365.8 & $\mathrm{AcP}^{\mathrm{B}} \quad 0.771$ \\
\hline & $\mathrm{B}$ & 619 & 615.8 & \multirow{2}{*}{$\begin{array}{c}\chi^{2}=0.40 \\
0.5<\mathrm{p}<0.7\end{array}$} \\
\hline & Total & 1,036 & $1,035.9$ & \\
\hline \multirow[t]{4}{*}{ EsD } & 1 & 830 & 848.1 & $\mathrm{EsD}^{1} \quad 0.634$ \\
\hline & $2-1$ & 1,016 & 979.2 & EsD $^{2} \quad 0.366$ \\
\hline & 2 & 264 & 282.6 & $\chi^{2}=2.99$ \\
\hline & Total & 2,110 & $2,109.9$ & $0.05<\mathrm{p}<0.1$ \\
\hline \multirow[t]{4}{*}{ GPT } & 1 & 238 & 226.7 & GPT $^{1} \quad 0.623$ \\
\hline & $2-1$ & 252 & 274.3 & GPT $^{2} \quad 0.377$ \\
\hline & 2 & 94 & 83.0 & $\chi^{2}=3.83$ \\
\hline & Total & 584 & 584.0 & $0.05<\mathrm{p}<0.1$ \\
\hline \multirow[t]{4}{*}{ 6-PGD } & A & 730 & 727.8 & PGDA 0.921 \\
\hline & $\mathrm{AC}$ & 120 & 124.9 & PGDC 0.079 \\
\hline & $\mathrm{C}$ & 8 & 5.4 & $x^{2}=1.45$ \\
\hline & Total & 858 & 858.1 & $0.2<\mathrm{p}<0.3$ \\
\hline
\end{tabular}


These frequencies are in general, except in GPT system, similar to the values in the data previously reported for other districts of Japan (in average, AcPA $0.210 \pm 0.051$, EsD $^{1} 0.635 \pm 0.033, \mathrm{GPT}^{1} 0.601 \pm 0.018$ and 6-PGDA $0.911 \pm 0.011$, Ishimoto, 1974). The GPT ${ }^{1}$ gene frequency in Fukushima Prefecture is 0.623 . On the one hand it is reported to be 0.535 in Okinawa, 0.592 in Kagoshima and 0.612 in Hiroshima. This fact suggests that the GPT ${ }^{1}$ gene frequency decreases gradually from the northern part towards the south in Japan.

\section{Gc system}

The isoelectric focusing patterns of Gc observed in the present study are shown in Fig. 1, presenting 18 phenotypes. At the International Workshop on the Gc-system
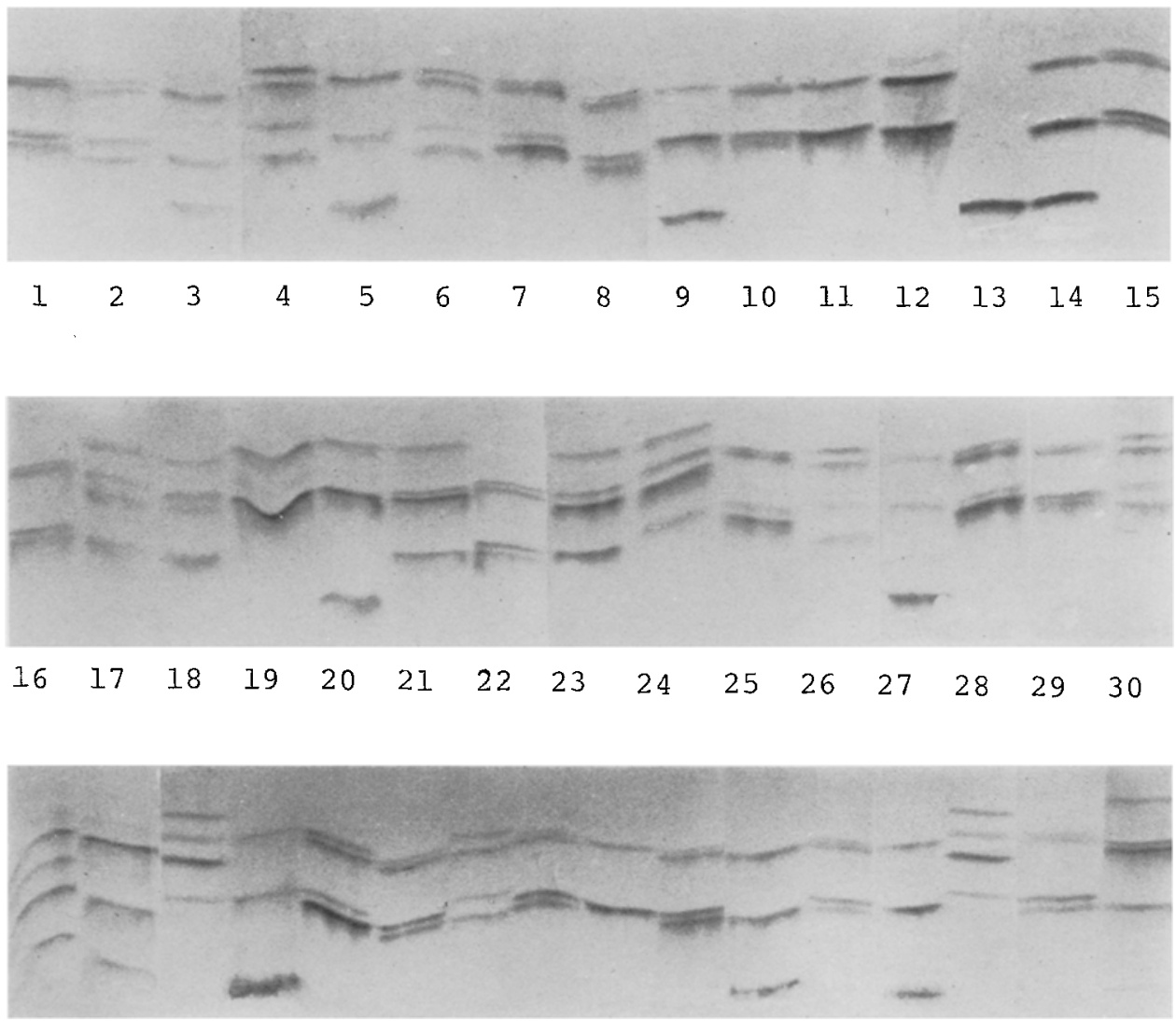

\section{$\begin{array}{llllllllllllllll}31 & 32 & 33 & 34 & 35 & 36 & 37 & 38 & 39 & 40 & 41 & 42 & 43 & 44 & 45 & 46\end{array}$}

Fig. 1. Isoelectric focusing patterns of $\mathrm{Gc}$ observed in this study. 1F-1F:11, 39. 1F-1S: $1,8,10,15,16,22,29,36,38,40,42,45$. 1S-1S: 12. 2-1F: 9, 43. 2-1S: 3, 14, 32, 41. 2-2: 13. 1A2-1F: 7, 25, 28, 35 . 1A2-1S: 6, 30, 37. 1A2-2: 5, 27, 34. 1A2-1A9: 24, 33, 44. 1A3-1S: 4, 26. 1A8-1S: 17, 18. 1A9-1F: 23. 1A9-1S: 21, 46. 1A9-2: 20. 1A9-1A9: 19. 1C2-1F: 2. 1C4-1F: 31 . 


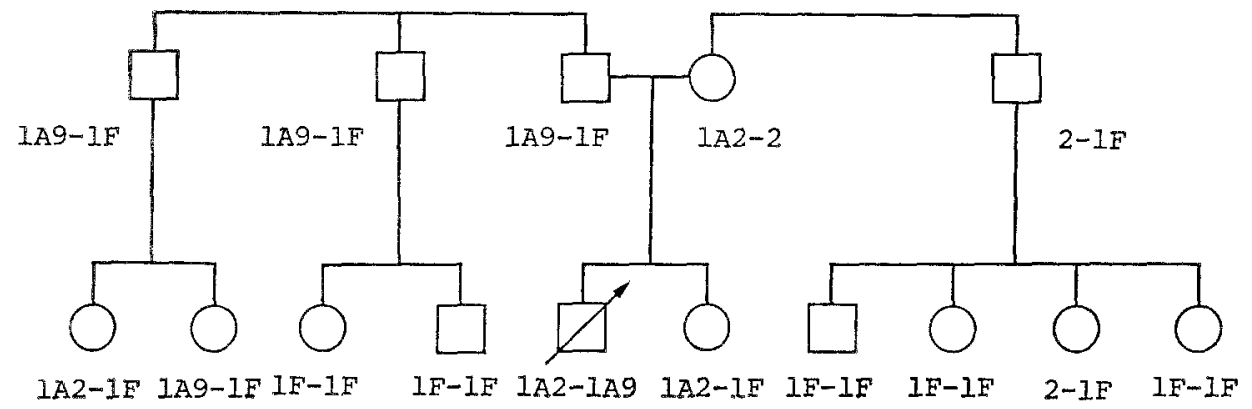

Fig. 2. Pedigree of a family illustrating the transmission of the Gc variant (1A2-1A9).

Table 2. Distribution of Gc subtypes in Fukushima Prefecture.

\begin{tabular}{|c|c|c|c|c|c|}
\hline Subtypes & No. Obs. & No. Exp. & Subtypes & No. Obs. & No. Exp. \\
\hline $1 F-1 F$ & 203 & 210.4 & $1 \mathrm{~A} 9-1 \mathrm{~F}$ & 4 & 4.9 \\
\hline $1 F-1 S$ & 214 & 208.2 & 1A9-1S & 2 & 2.4 \\
\hline $1 \mathrm{~S}-1 \mathrm{~S}$ & 54 & 51.5 & $1 \mathrm{~A} 9-2$ & 1 & 2.5 \\
\hline $2-1 F$ & 222 & 214.0 & $1 \mathrm{~A} 9-1 \mathrm{~A} 9$ & 1 & - \\
\hline $2-1 S$ & 93 & 105.9 & $1 \mathrm{C} 2-1 \mathrm{~F}$ & 1 & 0.5 \\
\hline $2-2$ & 60 & 54.4 & $1 \mathrm{C} 4-1 \mathrm{~F}$ & 1 & 0.5 \\
\hline $1 \mathrm{~A} 2-1 \mathrm{~F}$ & 19 & 17.0 & Others & - & 3.0 \\
\hline 1A2-1S & 10 & 8.4 & & & \\
\hline $1 \mathrm{~A} 2-2$ & 5 & 8.6 & & $\chi^{2}=16.63$ & \\
\hline $1 \mathrm{~A} 2-1 \mathrm{~A} 9$ & 1 & 0.2 & & $0.50<\mathrm{p}<0.75$ & \\
\hline $1 \mathrm{~A} 3-1 \mathrm{~S}$ & 1 & 0.3 & & (d.f. $=18)$ & \\
\hline \multirow[t]{2}{*}{ 1A8-1S } & 1 & 0.3 & & & \\
\hline & & & Total & 893 & 893.0 \\
\hline
\end{tabular}

Table 3. Gene frequencies of Gc in Fukushima Prefecture and other populations in Japanese.

\begin{tabular}{|c|c|c|c|c|}
\hline Alleles & $\begin{array}{l}\text { Fukushima } \\
\text { (Present study) }\end{array}$ & $\begin{array}{c}\text { Tokyo } \\
\text { Nakajima } \\
(1980)\end{array}$ & $\begin{array}{c}\text { Osaka } \\
\text { Matsumoto } \\
(1979)\end{array}$ & $\begin{array}{c}\text { Nagasaki } \\
\text { Iwasaki } \\
\text { (1982) }\end{array}$ \\
\hline$G c^{1 F}$ & 0.4854 & 0.4782 & 0.4209 & 0.4409 \\
\hline $\mathrm{Gc}^{1 \mathrm{~S}}$ & 0.2402 & 0.2507 & 0.3006 & 0.2356 \\
\hline $\mathrm{Gc}^{2}$ & 0.2469 & 0.2450 & 0.2579 & 0.2909 \\
\hline $\mathrm{Gc}^{1 \mathrm{~A}^{2}}$ & 0.0196 & 0.0204 & \multirow{2}{*}{\multicolumn{2}{|c|}{ (Gc $\left.\mathrm{c}^{\text {variants }}\right)$}} \\
\hline $\mathrm{Gc}^{1 \mathrm{~A}^{3}}$ & 0.0006 & 0.0014 & & \\
\hline $\mathrm{Gc}^{1} \mathrm{~A}^{8}$ & 0.0006 & 0.0009 & 0.0206 & 0.0326 \\
\hline $\mathrm{Gc}^{1 \mathrm{~A}^{9}}$ & 0.0056 & 0.0033 & & \\
\hline $\mathrm{Gc}^{1 \mathrm{C}^{2}}$ & 0.0006 & - & & \\
\hline $\mathrm{Gc}^{1 \mathrm{C} 4}$ & 0.0006 & - & & \\
\hline
\end{tabular}


held in 1978, the Gc phenotypes determined by a total of 30 alleles were demonstrated. At that time it was proposed to unite new nomenclatures of variants in place of the designations used independently by investigators. Cleve et al. (1981) reported that $6 \mathrm{Gc}$ phenotypic variants, observed in Japanese and called $\mathrm{GcJa}, \mathrm{Jb}, \mathrm{Jd}$, Mie and $\mathrm{Ok}$, were found to be identical with Gc1A2, 1A3, 1A9, 1A8, 1C4 and 1C2. These represent double band variants and are presumably mutants of the $\mathrm{Gc}^{1}$ allele. All of these 6 alleles are observed in the present study. Two rare phenotypic variants, 1A9-1A9 and 1A2-1A9, are also observed. The former is a homogeneity of one variant allele and the latter is a heterogeneity of two variant alleles. Family study on 1A2-1A9 indicates that the variant inherits as a codominant character (Fig. 2).

The distribution of Gc subtypes and gene frequencies are shown in the Tables 2 and 3, respectively. There is a good agreement between the observed and the expected numbers of these subtypes (Table 2). The result of Gc gene frequencies in Fukushima Prefecture is summarized in Table 3, comparing with these in the other populations in Japanese. The gene frequencies of $\mathrm{Gc}$ in Tokyo are nearly identical with our present study. We observe a higher $\mathrm{Gc}^{1 \mathrm{1F}}$ frequency $(0.4854)$ than that found in Osaka (0.4209) and in Nagasaki (0.4409), and a lower $\mathrm{Gc}^{1 \mathrm{~S}}$ frequency $(0.2402)$ than that in Osaka (0.3006). The $\mathrm{Gc}^{2}$ frequency $(0.2469)$ is in agreement with that reported in Tokyo $(0.2450)$, on the contrary it is lower than that reported in Osaka (0.2579), Mie (0.263, Ishimoto et al., 1979) and Nagasaki (0.2909). This result indicates that the $\mathrm{Gc}^{2}$ gene frequency gradually increases from east to west in Japan. The Gcvariants frequency is found to be 0.0276 , ranging in the values reported in other districts. Therefore, the alleles of Gcvariants are distributed widely in Japanese.

Kuwata et al. (1978) examined Gc polymorphic frequency in Fukushima Prefecture using an agar gel immunoelectrophoresis, and estimated the $\mathrm{Gc}$ frequencies of $\mathrm{Gc}^{1} 0.7285, \mathrm{Gc}^{2} 0.2463$ and $\mathrm{Gc}^{\mathrm{J}} 0.0252$. There is no significant difference between these values and the ones presented in our study, that is, $\mathrm{Gc}^{1} 0.7256, \mathrm{Gc}^{2} 0.2469$ and Gcothers 0.0276 .

Acknowledgment We are grateful to Dr. H. Nakajima, Department of Forensic Medicine, Tokyo Medical and Dental University, for Ge standard samples provided, and Mr. K. Satoh, Fukushima Red Cross Blood Center, for blood samples. For generous offers we thank Mr. M. Ohno and his family.

\section{REFERENCES}

Cleve, H., Constans, J., Berg, S., Hoste, B., Ishimoto, G., Matsumoto, H., Spees, E.K., and Weber. W. 1981. Ge revisited: six further Gc-phenotypes delineated by isoelectric focusing and by polyacrylamide gel electrophoresis. Hum. Genet. 57: 312-316.

Constans, J., Viau, M., Cleve, H., Jaeger, G., Quilici, J.C., and Palisson, M.J. 1977. Analysis of the $\mathrm{Gc}$ polymorphism in human populations by isoelectrofocusing on polyacrylamide gels. Demonstration of subtypes of the $\mathrm{Gc}^{2}$ allele and of additional Gc variants. Hum. Genet. 41: 53-60. 
Constans, J., Viau, M., Pison, G., and Langaney, A. 1978. Gc subtypes demonstrated by isoelectric focusing: further data and description of new variants among an African sample (Fula) from Senegal. Jph. J. Human Genet. 23: 111-117.

Hopkinson, D.A., Spencer, N., and Harris, H. 1964. Genetical studies on human red cell acid phosphatase. Am. J. Hum. Genet. 16: 141-154.

Ishimoto, G., and Kuwata, M. 1973. Red cell enzyme polymorphism in Japanese populations: a study on distribution of the phenotypes and forensic use in paternity cases. Jpn. J. Legal Med. 27: 134-141.

Ishimoto, G. 1974. Red cell enzymes. In JIBP Synthesis 2. Univ. Tokyo Press, Tokyo, pp. 109-139.

Ishimoto, G., Kuwata, M., and Nakajima, H. 1979. Group-specific component (Gc) polymorphism in Japanese: an analysis by isoelectric focusing on polyacrylamide gels, Jpn. J. Human Genet. 24: 75-83.

Iwasaki, M., Fukae, T., Nakasono, I., Suyama, H., and Tomohiro, Y. 1982. The distribution of Ge subtypes in Nagasaki district. Presented at the 66th general meeting of the Medico-Legal Society of Japan.

Kuwata, M., Ishimoto, G., and Nakajima, H. 1978. Group-specific component (Gc) polymorphism in Japanese: an investigation on the phenotypic distribution with regard to the $\mathrm{Gc}^{J}$ allele. Jpn. J. Human Genet. 23: 127-132.

Matsumoto, H., Toyomasu, T., Tamaki, Y., Katayama, K., and Matsui, K. 1979. The distribution of Ge subtypes in Japanese and its application in paternity case. Jpn. J. Legal Med. 33: 74-79.

Nakajima, H., and Nakazawa, E. 1980. The Gc subtypes in Japanese: further population and family samples. Jpn. J. Legal Med. 34: 1-8.

Viau, M., Constans, J., and Bouissou, C. 1977. Achievement of a linear gradient of range one pH unit in isoelectric focusing. Sci. Tools $24: 25-26$. 